\title{
Devletlerin Terörizmin Finansmanının Önlenmesi Politikalarının Oluşumu: Küresel Yönetişim ve Mali Eylem Görev Gücü Etkisi
}

\begin{abstract}
Ahmet BARBAK ${ }^{1}$
$\ddot{O} z$

Bu makale, terörizmin finansmanının önlenmesi politikasını küresel yönetişim bağlamında incelemektedir. Birleşmiş Milletler tarafindan Terörizmin Finansmanının Önlenmesi Uluslararası Sözleșmesinde düzenlenen bu politika, 2000'li yıllardan itibaren küresel bir politika niteliği kazanmıştır. Bu politikanın küreselleşmesinde ve küresel yönetişimin oluşumunda Mali Eylem Görev Gücü (MEGG)'nün rolü göze çarpmaktadır. $M E G G$, biçimsel bir uluslararası örgüt olmamasına rağmen devletler karşısında zorlayıcı uyum mekanizmalarına sahiptir. MEGG, bölgesel olarak kurulan MEGG benzeri yapılar yoluyla geniş bir alanı kontrol etmektedir. MEGG'in yapısal ve işlevsel incelenmesiyle, devletlerin küresel yönetişim ile ilişki kurma biçimleri görülebilir. Bu çalışmada alanyazından küresel yönetişimin tanımlayıcı özellikleri çıkarılmaya çalışılmış ve MEGG bu özelliklere göre karşılaştırmalı olarak incelenmiștir.
\end{abstract}

Anahtar Kelimeler: Küresel Yönetişim, Terörizmin Finansmanı, Mali Eylem Görev Gücü

JEL Sinıflandırma Kodları: F50, F65, G28

\section{The Formation of States' Policies of Prevention of Terrorism Financing: Global Governance and The Influence of Financial Action Task Force}

\begin{abstract}
This article examines the policy of preventing terrorism financing within the context of global governance. The policy which was organized in International Convention for the Suppression of Financing of Terrorism by United Nations has gained the quality of a global public policy since 2000's. The role of Financial Action Task Force (FATF) in globalisation of the policy as well as in the formation of global governance draws attention. FATF possesses mechanisms of coercive compliance against states considering that it differs from formal international organizations. FATF controls a wide territory by FATF Style Regional Bodies. By examining FATF's structural and functional aspects, it can be observed the states' ways of establishing relationships with global governance. In this study, having extracted the descriptive features of global governance from the literature, FATF was examined according to these features.
\end{abstract}

Keywords: Global Governance, Terrorism Financing, Financial Action Task Force

JEL Classification Codes: F50, F65, G28

1 Yrd. Doç. Dr., İzmir Katip Çelebi Üniversitesi, İktisadi ve İdari Bilimler Fakültesi, Siyaset Bilimi ve Kamu Yönetimi Bölümü, abarbak01@gmail.com 


\section{A. BARBAK.}

\section{GİRIŞ}

Terörizmin finansmanı, 1990'lardan itibaren uluslararası gündeme taşınan bir sorun alanıdır. Terörizmin finansmanının önlenmesi için uluslararası alanda ortaya çıkan örgütlenmelerin, küresel yönetişim özelliklerini taşıdığı söylenebilir. Bunun için küresel yönetişime ilişkin tanımlayıcı özelliklerin ortaya konulması gerekmektedir. Zira küresel yönetişim, dünyada küreselleşme lehine paradigma değişimlerinin yaşandığı belirli bir döneme ait bir olgu ve kavramdır. Bu dönem, devlet aygıtını devlet dıșı aktörler lehine sınırlamayı amaçlayan yönetișim yaklaşımın geliştiği ve devlet dışı aktörlerin çoğaldığı bir dönemdir.

20'nci yüzyılın sonundan itibaren dünyanın genelinde hemen hemen her alanda ortaya çıkan köklü değişim ya da buna yönelik talepler, küreselleşme kavramıyla açılanmaktadır. Küresel yönetişim ile küreselleşme olguları arasındaki ilişki çeşitli şekillerde açıklanabilir. Küresel yönetişim küreselleşmenin kendisi midir? Yoksa bir nedeni midir? Ya da küreselleşme küresel yönetişimi mi ortaya çıkarmıştır? Bu çalışmada böyle bir tartışmaya girmeksizin, küresel yönetişimin küreselleşme sürecinin kurumlaşma biçimi olduğu savunulmaktadır. ${ }^{2}$ Terörizmin finansmanının önlenmesine ilişkin uluslararası politika da bir küresel yönetişim örneği olușturmaktadır.

$\mathrm{Bu}$ çerçevede makale, terörizmin finansmanının önlenmesi politikasının oluşumunu küresel yönetişim kavramı çerçevesinde incelemektedir. Terörizmin finansmanının önlenmesi, 1990'lardan itibaren uluslararası örgütlerin gündemine girmiştir. BM tarafından Uluslararası Terörizmin Finansmanının Önlenmesi Sözleșmesinde düzenlenen bu politika, 2000'li y1llardan itibaren küresel bir

\footnotetext{
2 Küreselleşme, bir yaklaşım, bir süreç ve bir örgütlenme biçimi olarak ele alınabilir. Yaklaşım olarak küreselleşme, siyasal otoritenin devlet dışında örgütlenmesine yönelik bir yaklaşımı ifade etmektedir. Süreç olarak küreselleşme ise, siyasal otoritenin devlet dışında örgütlenmesindeki değişimin zaman içerisinde ortaya çıkması (küresel yönetişim yaklaşımı açısından bir ilerleme) durumu olarak tanımlanabilir. Bu çerçevede, örgütlenme biçimi olarak küreselleşmenin kendisine ait ilke, kural, norm ve örgütleri olan bir kurumlaşma olduğu ileri sürülebilir.
} 
politika niteliği kazanmıştır. Bu süreçte, Mali Eylem Görev Gücü (MEGG)'nün rolü göz ardı edilmemelidir.

Çünkü MEGG, biçimsel uluslararası örgütlerden farklılık göstermesine rağmen devletlere yönelik doğrudan ve dolaylı zorlayıcı uyum mekanizmalarına sahiptir. Terörizmin önlenmesine ilişkin olarak uluslararası standartlar belirleyen MEGG'in küresel yönetişime özgü bir örgütlenme biçimi olduğu ileri sürülebilir. MEGG’in yapısal ve işlevsel özelliklerinin incelenmesiyle de, devletlerin küresel yönetişimle ilişki kurma biçimlerini görmek mümkündür.

Bu kapsamda, çalışmada öncelikle küresel yönetişimin tanımlayıcı özellikleri çıkarılmaya çalışılmış ve MEGG yapısal ve işlevsel olarak incelenmiştir. Daha sonra, küresel yönetişimin tanımlayıcı özellikleri çerçevesinde MEGG ve MEGG'in devletlerle ilişki kurma biçimleri tartışılmıştır. Böylece küresel yönetişimin belirli bir politika alanında örgütlenmesi gösterilmeye çalışılmıştır.

\section{KÜRESEL YÖNETIŞi̇iM: SIYYASAL OTORITENIN DEVLET DIŞINDA ÖRGÜTLENMESİ}

Küresel yönetişim, yönetişim ve küreselleşme olgularının birlikte varlık gösterdiği bu dönemin kendine özgü koşullarında ortaya çıkan; temelde yönetişimin küresel ölçekte uygulamaya geçirilmesine dayanan bir durumu ifade etmektedir. 20'nci yüzyllın sonunda başlayan köklü değişikliklerin nedeni kabul edilen bu iki olguyu bir araya getiren bir kavramın daha fazlasını ifade ettiğini söylemek yanlış olmayacaktır.

Yönetişim, siyasal otorite ile ilgili bir kavramdır. Bu bağlamda yönetişim, siyasal iktidarın kullanımına devlet dışı aktörlerin (uluslararası örgütler, hükümet dışı örgütler, sivil toplum örgütleri vd.) çeşitli analiz seviyelerinde (ulus altı, ulusal ve uluslararası) katılımını ve siyasal otoritenin devlet ve devlet dışı aktörler arasında bölünme ve yeniden bütünleşmesini ifade etmektedir (Rhodes, 1996; Finkelstein, 1995: 369; Weiss ve Gordenker, 1996: 17; Carayannis vd., 2012).

Krahmann (2005) yönetişimi, politika sürecinin farklı aşamalarındaki yatay farklılaşma olarak tanımlamaktadır. Bu durum küresel yönetişimde, politika 


\section{A. BARBAK.}

sürecinin farklı aşamalarında devlet ve devlet dışı aktörlerin müdahil ve/veya belirleyici olduğu bir durumu ifade etmektedir (Carayannis vd., 2012). Politika sürecinde eşanlı bölünme ve bütünleşme bir çelişki gibi görünmekle birlikte, buradaki durum, otorite bölündükçe otoritenin bölündügü aktörler arasında eşgüdüm ve işbirliğine olan ihtiyacın artmasıdır.

Küreselleşme kavramı da, belirli bir tanıma sahip olmaktan ziyade, olay ve olguların küreselleşme kavramı altında açıklanması yoluyla anlam kazanmaktadır. Küreselleşme genellikle, ekonomilerin, toplumların ve ulusların arasında artan bir etkileşim ve karşılıklı bağımlılık süreci olarak tanımlanır (Vujakovic, 2010). Bunun yanı sıra küreselleşme, devletlerin uluslararasılaştırılması ve küreselleşen dünyanın kurumları haline getirilmesi (Cox, 1994) ya da siyasal ve ekonomik kazançlar sağlamak üzere geliştirilen söylem, pratik ve ideolojilerden oluşan yapılar (Walck ve Bilimoria, 1995: 3) şeklinde de tanımlanmaktadır.

$\mathrm{Bu}$ çalışmada küreselleşme, ulusal olanı küresel olana, gelişmekte olanı gelişmiş olana bağlamak ve uyarlamak amacıyla bunlar arasında hiyerarşik bir ilişki kuran ve kendine özgü kurumlarla (küresel yönetişim) bu ilişkiyi yeniden üretmeye ve sürdürmeye çalışan yapılar ve bu yapıların gelişim süreci olarak ele alınmaktadır. Küreselleşmenin ortaya çıktığı yer, politika sürecinin kendisidir. Bir diğer deyişle, küresel olan ile ulusal olan arasındaki bağ ekonomik, siyasal ve toplumsal politika alanlarında gelişmektedir. Bu süreçte, küresel olandan ulusal olana kuram, kavram, ilke, norm, kural ya da standart biçimlerinde bir akış varken ulusal olandan küresel olana da bir taahhüt akışından söz edilebilir. ${ }^{3}$

Küreselleşme, ulusal olanı küresel olana bağlama ve uyarlama biçiminde ortaya çıkarken bu bağlanma ve uyumun derecesi de belirli bir zamanda ve mekânda

\footnotetext{
${ }^{3}$ Burada taahhüt kavramı ekonomik, siyasal ya da toplumsal bağlamlarda geleceğe dönük bir üstlenmeyi, kabullenmeyi ve uyma davranışını ifade edecek biçimde kullanılmıștır. Genel olarak bu durumu, küresel rıza üretimi süreci olarak da nitelemek mümkündür. Ulus devlet sisteminde devlet-yurttaş ilişkisindeki bu rıza üretimi (Hoare ve Smith, 1992), küreselleşme sürecinde küresel yönetişim ile devlet ve yurttaş arasında ortaya çımaktadır. Böyle bir yapıda devletin küresel yönetişim ile yurttaş arasında bir rıza aracı olarak işlev gördüğü de ileri sürülebilir.
} 
küreselleşmenin aldığı mesafeye işaret etmektedir. Buna göre, küresel politikalara uyum arttıkça küreselleşme derecesinin de artacağı ileri sürülebilir. Bu bağlamda, küreselleşme zamanın ve mekânın bir fonksiyonu olarak ifade edilebilir. (Harvey, 1989; Giddens, 1998; Scholte, 2007). Yani küreselleşme derecesi zamana ve mekâna bağlı olarak değişebilecektir.

Günümüzde küreselleşme, ulusal ve uluslararası yapıları dönüştürerek küresel yönetişim şseklinde belirmektedir (Wendt, 1992; Rosenau, 1997; Zürn, 1998). Küresel Yönetişim Komisyonu, küresel yönetişimi birbiriyle çatışan ya da birbirinden farklı çıkarların bir arada bulunduğu, ancak işbirliğine dayalı eylemin öngörüldüğ̈̈ devamlı bir süreç olarak tanımlamaktadır (Commission on Global Governance, 1995: 2). Bu tanıma göre, küresel yönetişim işbirliği temelinde yani davranışsal bağlamda ortaya çıkması istenen, değerlerin paylaşımı yerine uygulamada birlikteliği savunan bir siyasal örgütlenme biçimidir. Devletin varlığını sürdürdüğü günümüzde, belirli bir sürede ve/veya kısmen ortaya çıkan değer paylaşımı yerine politika ölçeğinde bir işbirliği küresel yönetişimin inşası açısından temel kabul edilmektedir.

Rosenau (1999), küresel yönetişimi dünyadaki herkesi kapsayan bir siyasal otorite olmadı̆̆ durumda karşılıklı bağımlılık ilişsilerinin düzenlenmesi olarak tanımlamaktadır. Keohane (2002), küresel yönetişimi küresel ölçekte kural koyma ve güç uygulama olarak tanımlarken bunun genel bir anlaşmayla yetkilendirilmiş bir kuruluşa dayanmasının gerekli olmadığını da belirtmektedir. Hettne (2002)'ye göre küresel yönetişim, ulus devletin siyasal otoritesinin mutlak kontrolünün ötesinde, küreselleşmiş bir alanda bir takım aktörlerin, sürekli ya da tam anlamıyla örgütlenmiş olmayan karar alma ve eylemde bulunma yetkisini ifade etmektedir. Overbeek (2004) ise, küresel yönetişimi, dünyanın tamamını ve onu oluşturan parçaları potansiyel olarak etkileyen politika alanlarındaki değerlerin çeşitli araçlarla bir yetkeye dayalı dağıtımı olarak tanımlarken küresel yönetişimin neoliberal küreselleşme çağının yönetişim biçimi olduğunu savunmaktadır.

Küresel yönetişim, ulus üstü ve ulus aşırı otorite örgütlenmesine dayanmaktadır. Ulus üstü yönetişim, uluslararası normların ve kuralların devletlere 


\section{A. BARBAK.}

bir yükümlülük oluşturduğu hatta devletlerin uymaması durumunda yaptırımla karşı karşıya kaldıkları bir durumu ifade etmektedir. Sonuç olarak, siyasal otorite kısmen uluslararası seviyeye doğru yer değiştirmektedir (Kahler ve Lake, 2009: 246). Ulus aşırı yönetişim ise, ulus aşırı aktörlerin devletler tarafından resmi olarak yetkilendirilmeden siyasal nitelikli düzenlemeleri yapmaları ve bunlara ilişkin faaliyetleri gerçekleştirmeleri sürecini ifade etmektedir (Zürn, 2013: 408-411).

Küresel yönetişim, bir kontrol mekanizması olarak da nitelenebilir. Buna göre, küresel yönetişimin kurumlaşma derecesine bağlı olarak belirli politika alanlarının ve coğrafyanın kontrol altına alındığı görülmektedir (Finkelstein, 1995; Weiss, 2000). Bu bağlamda, küresel yönetişim devlet dışı yönlendirme, yönetim ya da sevk-idare mekanizmaları oluşturarak, ulusal-uluslararası dikotomisinin ötesinde özerk otorite alanlarının ortaya çıkışıyla kendisini göstermektedir (Dingwerth ve Pattberg, 2006: 196-198). Bu özerk otorite alanlar1 ise küresel politika süreci tasarımları şeklinde ortaya çıkmaktadır.

20’nci yüzyılın sonunda politika sürecinde ortaya çıkan değişim, politika sürecinin devlet dışı aktörleri içine alacak şekilde genişlemesi ve ulus üstü ölçekte yürütülecek şekilde küreselleşmesidir (Witte vd., 2000). Bu iki olgunun somut görünümü politika ağları şeklinde ortaya çıkmaktadır. Bu çalışmada politika ağı, yönetişimin belirli bir biçimi olarak ele alınmaktadır. Küresel yönetişim bir ă olarak ele alınırsa bu yapıdaki devlet, ăg devleti olarak adlandırılır (Castells, 2006: 87-89). A $\breve{g}$ devleti, egemenliğini ve sorumluluğunu paylaşmakta; bu devletin yurttaşları ve diğer devlet ve devlet dışı aktörlerle olan ilişkileri bu çerçevede öncesinden farklılaşmaktadır.

Yönetişim biçimi olarak politika ağları, kamu ya da özel, devlet ya da devlet dışı, ulus altı, ulusal, ulus üstü aktörlerin belirli bir politika alanında kendi amaç ve çıkarları çerçevesinde bir araya geldiği ve etkileşim içerisinde bulunduğu, çeşitli derecelerde kurumsallaşmış yapıları ifade etmektedir. Börzel (1997)'e göre, ortaya çıkan durum, yatay eşgüdüm sağlamaya dönük olarak politika ağları yoluyla 
yönetişim sağlanmasıdır. $\mathrm{Bu}$ çerçevede, politika ağlarının temel kaygısı aktörler arasında eşgüdüm sağlanması ve pazarlık yoluyla kolektif karar alınmasıdır.

Politika ağının bir alt politika alanında ya da belirli bir işlevinde merkezi konumda olan bir aktör, politika ağının başka bir alt alanında ya da işlevinde merkez dişı konumda yer alabilmektedir (Sobacı, 2013). Örneğin, terörizmin finansmanının önlenmesinde BM merkezi konumda yer alırken uluslararası finansal sistem ya da yapısal uyarlama politikalarında uluslararası mali kuruluşlar (IMF, DB) veya Ekonomik İşbirliği ve Kalkınma Örgütü (OECD) gibi örgütler öne çıkmaktadır.

Görüldüğü üzere, küresel yönetişime ilişkin olarak alanyazında çeşitli tanımlar yapılmakta ve bu kavrama çeşitli özellikler atfedilmektedir. Geliş(tiril)meye devam eden bir kavram ve politika olarak küresel yönetişim, mümkün olduğunca geniş tanımlanmaktadır. Bununla birlikte, küresel yönetişimin tanımlayıcı özelliklerini bütüncül olarak ortaya koymak mümkündür (Tablo-1).

Tablo 1. Küresel Yönetişimin Tanımlayıcı Özellikleri

\begin{tabular}{|c|c|c|}
\hline \multicolumn{2}{|c|}{ Tanımlayıcı Özellik } & Yöntem \\
\hline \multirow{6}{*}{ 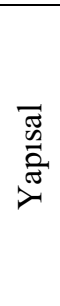 } & Otorite örgütlenmesi & Ulus üstü ve ulus aşırı yetki aktarımı \\
\hline & Kurumlaşma & Farklı derecelerde kurumsallaşma \\
\hline & Yatay farklılaşma & Otoritenin bölünmesi (devlet-devlet dışı) \\
\hline & Tematik örgütlenme & Belirli bir (alt) politika alanına bütüncül bakış \\
\hline & A ̆g tipi örgütlenme & $\begin{array}{c}\text { İ̀sbirliği, eşgüdüm, uzlaşma, uyum; çok kademeli } \\
\text { yönetişim }\end{array}$ \\
\hline & Esnek örgütlenme & En az hiyerarşi; yatay eşgüdüm. \\
\hline \multirow{3}{*}{ 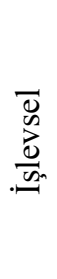 } & Otorite kullanımı & $\begin{array}{c}\text { Resmi olmayan kuruluşlar; küresel düzenleme; } \\
\text { kolektif güç }\end{array}$ \\
\hline & Politika uyumu & $\begin{array}{l}\text { Arabuluculuk ve uzlaşma, küresel kural ve } \\
\text { standartlara uyum, ortak çıkar, hak ve } \\
\text { yükümlülükler, ortak politika ortak çözümleri }\end{array}$ \\
\hline & Kontrol mekanizması & $\begin{array}{l}\text { Kurallar sistemi, standart, koşul ve politika; } \\
\text { uyum izleme ve değerlendirme }\end{array}$ \\
\hline
\end{tabular}

Tablo-1'e göre, küresel yönetişimin yapısal olarak; siyasal otoritenin örgütlenmesinde ulusal olandan ulus üstü olana, biçimsel olandan biçimsel olmayana, dikey farklılaşmadan yatay farkl1laşmaya, işlevsel örgütlenmeden tematik örgütlenmeye doğru bir hareket olduğunu söylemek mümkündür. Küresel 


\section{A. BARBAK.}

yönetişime işlevsel olarak bakıldığında ise, temelde bir kontrol mekanizmasının oluşturulmasının öngörüldügü; bunun için işbirliği, eşgüdüm, uyum, kural koyma, standart belirleme, arabuluculuk ve uzlaşma işlevlerinin yerine getirildiği görülmektedir. $\mathrm{Bu}$ tanımlayıcı özelliklerin aynı zamanda küresel yönetişsimin kurumlaşma derecesini belirlediği de iddia edilebilir.

\section{KÜRESEL YÖNETIŞIM OLARAK ULUSLARARASI TERÖRIZMIN} FINANSMANININ ÖNLENMESİ

\subsection{Küresel Yönetişimin Ortaya Çıkışı: Birleşmiş Milletler ve "Güvenlik-} Finans" İlişkisi Tasarımı

Terörizmin finansmanının bir güvenlik sorunu olduğu yadsınamaz bir gerçektir. Ancak politikanın gövdesini ulusal ve uluslararası finansal sistem oluşturmaktadır. Bir başka deyişle, bu politika adına yapılanlar, her şeyden çok finans sistemiyle ilgilidir. Terörizmin finansmanı, "güvenlik" ve "finans" alanları arasında doğrudan ve küresel ölçekte bir bağ kurarak uluslararası bir politika alanı oluşturmaktadır. $\mathrm{Bu}$ olgu, finans alanının güvenlikleştirilmesi ya da güvenlik alanının genişlemesi olarak değerlendirilebilir. ${ }^{4}$

Politika alanlarından birisi olarak finansın güvenlikleştirilmesi ise, kamusal ve özel finansal sistemin güvenlik politikaları temelinde örgütlenmesi anlamına gelmektedir. Burada, finansal sistemin kontrol ve denetim otoritesinin teröre karş1 mücadele (yani güvenlik) gerekçesiyle artırılması söz konusudur. Terörizmin finansmanının önlenmesi de, finansal işlemlerin küresel yönetişı̇m yapısı tarafından izlenmesi, kontrol ve denetimi ile yaptırım (ceza dâhil) uygulanmasına yönelik

\footnotetext{
${ }^{4}$ Güvenlikleştirme, alanyazında Kopenhag Okulu'nun ileri sürdüğü ve 1990'lı yıllardan sonra güvenliğin kapsamının genişlemesi şeklinde ortaya çıkan durumu açıklamak için kullanılan bir yaklaşımı temsil etmektedir. Buzan vd. (1998: 25) güvenlikleştirmeyi, siyasallaşmanın aşırı bir versiyonu olarak nitelemekte ve diğer politika alanlarında güvenlik adına sıra dışı araçların kullanımına imkân veren bir yaklaşım olarak tanımlamaktadır. Güvenlik dışındaki politika süreçlerinin güvenlik politikasının amaç, hedef ve araçlarıyla biçimlendirilmesi ve bu politika alanlarının güvenliğin konusu olması, güvenlikleştirmeyi ifade etmektedir. Buzan vd. (1998), güvenlikleştirmenin meydana gelebileceği beş alan belirtmiştir: Askeri, siyasal, ekonomik, toplumsal, çevresel.
} 
uluslararası hukuk ve standartların geliştirilmesine dayanmaktadır. $\mathrm{Bu}$ durum, ekonomi alanının güvenlikleştirilmesi çerçevesinde değerlendirilebilir.

Finans alanının güvenlikleştirilmesi, 1980'lerden itibaren artan finansal serbestleşmenin aksine bir olgu olarak değerlendirilebilir. Ancak, 1990'lardan itibaren bir taraftan finansal krizlerin önlenmesi için öncelikle finansal kural ve kurumların oluşturulması gerektiği savunulurken (Kaminsky ve Schmukler, 2003; Broner ve Ventura, 2010), diğer taraftan hızla artan finansal işlemlerin izlenmesi, kontrol ve denetim altına alınması bir sorun alanı olarak görülmeye başlamıştır (FATF, 2015a).

Terörizmin finansmanının önlenmesine yönelik önlemler 1970'lere kadar götürülebilir. Avrupa'da, ulusal terör örgütlerine karşı tedbirler 1970’lerin sonunda alınırken, 1970'lerin başında Amerika Birleşik Devletleri (ABD) terörizmin sponsoru olarak nitelediği devletlerin ve örgütlerin finansal transferlerini durdurmaya ve finansal varlıklarını dondurmaya başlamıştır (Giraldo ve Trinkunas, 2007). 1990'larda, bu uygulama bireysel işlemlere kadar genişlemiştir (Levi, 2010: $652)$.

$\mathrm{Bu}$ süreçte, terörizmin tanımı konusunda fikir birliği olmadığı da söylenmelidir (The Institute for Economics and Peace, 2015). ${ }^{5} \mathrm{Bu}$ durum, neyin terörizmin finansmanı sayılacağını da muğlak hale getirmektedir. BM Uluslararası Terörizmin Finansmanının Önlenmesi Sözleşmesinde de, terörizmin finansmanı sayılacak haller belirtildiği ve böylece terörizm ve terörizmin finansmanı konusundaki bu farklılıkların BM sistemi ile aşılmaya çalışıldığı görülmektedir.

Terörizmin finansmanının önlenmesi konusunda küresel iktidar örgütlenmesini BM temsil etmektedir. BM, terörizmin finansmanının önlenmesine yönelik ilk

\footnotetext{
5 Terörizmin ortak bir tanımının yapılamamasında iki temel nedenden söz edilebilir. Bunlardan ilki, kavramsal sorundur. Yani terörizm gibi bir kavramı tanımlamanın bazı uç durumları kapsam dışı bırakacağı ya da ideolojik veya siyasal gerekçelerle yanlı olacağıdır (Gibbs, 1989). Uygulamadaki sorun ise, birisinin teröristi diğerinin özgürlük savaşçısl şeklinde ifade edilen durumdur (Lawless, 2007). Böylece hem devletler arasında hem de uluslararası örgütler ile devletler arasında terörizme ilişkin kavramsal ve pratik farklılıklar bulunmaktadır.
} 


\section{A. BARBAK.}

irade beyanını Aralık 1994'te bir Genel Kurul Kararıyla yapmıştır. Uluslararası terörizme karşı önlemlere ilişkin bu Kararda, devletlerin terörist eylemleri finanse etmekten kaçınması istenmiştir (United Nations, 1994). BM'nin, 1996 y1lından itibaren terörizmin finansmanı konusunu daha geniş bir perspektifle ele almaya başladığı ve bu konuya kararlarında daha fazla yer verdiği görülmektedir. 1996 yılında BM Genel Kurulu, üye devletlerin terörizmin finansmanını önlemek için uygun düzenleyici tedbirler almalarını ve bu alanda uluslararası bilgi paylaşımını yoğunlaştırmalarını istemiştir. Peki, burada uygun düzenleyici tedbir nedir?

$\mathrm{Bu}$ sorunun cevab1, öncelikle $\mathrm{BM}$ Genel Kurulu Kararlarında görülebilir. Karar'da, düzenleyici tedbirlerin meşru sermaye hareketlerinin serbestliğine engel olmaması ve bu konudaki bilgi paylaşımının yoğunlaştırılması istenmiştir (United Nations, 1996; United Nations, 1999). Burada, küresel serbest sermaye akışlarının engellenmesi kaygısı vardır. Zira bir taraftan uluslararası finansal serbestleşme sonucu kontrol zorlaşırken diğer taraftan finansal hareketler üzerinde daha fazla kontrol düzenlemeleri (finansal varlıkların dondurulması, bu varlıklara el konulması) öngörülmektedir.

$\mathrm{Bu}$ sürecin devamı olarak BM, Aralık 1999'da, terörizmin finansmanının önlenmesine ilişkin bir uluslararası sözleşme kabul etmiştir. Bu sözleşme, bir taraftan BM'nin terörizmin finansmanının önlenmesi konusundaki rolünü genişletirken diğer taraftan kurulmak istenen küresel yönetişimin yapısal ve işlevsel çerçevesini çizmektedir. Sözleşme metninde, mevcut çok taraflı hukuki düzenlemelerin açıkça terörizmin finansmanını önlemeye yönelik olmadığ belirtilerek bu konuda uluslararası işbirliğinin güçlendirilmesi istenmiştir. ${ }^{6}$ Sözleşme, ulusal sinırlar içerisinde yer alan finansal işlemlerin takip edilmesini ve terörizmin finansmanının devletlerin iç hukukunda bir suç olarak düzenlenmesini öngörmektedir (United Nations, 1999).

6 Sözleşmenin uygulanmasında devletler arasında anlaşmazlık çıkması durumunda Uluslararası Tahkim ve Adalet Divanı uygulaması da öngörülmüştür. Ancak uyuşmazlık durumuna ilişkin uygulamalar devletler için zorunlu tutulmamıştır. 
Sözleşmede, uluslararası terörizmin ve bunun finansmanının tek devletin değil tüm devletlerin ortak sorunu olduğunun belirtilmesi ve bu konuda devletler arasında işbirliğinin güçlendirilmesinin istenmesi, küresel yönetişimin inşası açısından bir ilerleme olarak kabul edilebilir. Ancak, sözleşmede "devletlerin egemenliği", "toprak bütünlüğü” ve "devletlerin birbirlerinin içişlerine müdahale etmemesi" ilkeleri esas alınmıştır. Bu ilkeler, işbirliğinde ulus devlet ölçeğinin esas alındığını göstermektedir.

Sözleşme kapsamındaki aktörler ise, BM Genel Sekreteri, üye devletler, tahkim sistemi ve Uluslararası Adalet Divanı'dır. Dolayısıyla mevcut uluslararası düzen içerisindeki aktörler arasında bir ilişki düzenlemesi yapılmıştır. Özellikle, tahkim ve Uluslararası Adalet Divanı uygulamasının devletlere zorunlu tutulmamış olması ve devletler arasındaki ilişkilerde egemenlik esasının korunacağının vurgulanması, o dönemde küresel yönetişimin Tablo-1'deki tanımlayıcı özelliklere göre gelişme aşamasının başında olduğunu göstermektedir.

\subsection{Küresel Yönetişimin Gelişiminde Küresel Düzenleyici Mekanizma}

\section{Olarak Mali Eylem Görev Gücü}

\subsubsection{Yapı ve İşlev: Küresel Yönetişimde Düzenleyici Mekanizma İnşası}

Küresel yönetişim ağının başlıca bileşenini ulusal ölçekte olduğu gibi bir düzenleyici mekanizma oluşturmaktadır. Bu düzenleyici mekanizma ise, küresel yönetişimin tanımlayıcı özelliklerini çeşitli derecelerde gösterecektir. Zira belirli bir politika alanının düzenlenmesi söz konusu olduğunda, küresel yönetişim yapısının düzenleyici bir yapı etrafında yoğunlaştığı görülmektedir. ${ }^{7}$ Bu çerçevede, küresel düzenleyici mekanizma kavramı ile kastedilen şey, belirli bir politika alanı ile ilgili olarak, devlet egemenliğinden ayrı özerk bir yapı olarak kural koyan, standartları belirleyen, değerlendirme yapan ve düzeltici (uyum sağlayıcı) eyleme yönlendiren örgütlenmelerdir.

\footnotetext{
${ }^{7}$ Bir düzenleyici mekanizma, dış çevredeki değişimlere rağmen iç çevreyi nispeten sabit ve belirli sınırlar içinde tutmaya çalışan bir kontrol sistemini ifade etmektedir. Bu tür mekanizmalar genellikle negatif geri besleme (istenmeyen bir durumun ortaya çıktığına dair bilgi aktarımı) sağlayan; sistemin herhangi bir değişkenindeki değişikliği tespit ederek aksi yönde bir değişiklik yapmaya çalışan mekanizmalardır.
} 


\section{A. BARBAK.}

Terörizmin finansmanına karşı küresel yönetişim kurumlaşması, 11 Eylül 2001 günü ABD'nin Newyork şehrinde bulunan Dünya Ticaret Merkezi binalarına gerçekleştirilen saldırılardan hızlanmış (Giraldo ve Trinkunas, 2007); bu alandaki uluslararası işbirliği ise, saldırının hemen ardından terörizmin finansmanının önlenmesiyle görevlendirilmiş MEGG etrafinda yoğunlaşmıştır (OECD, 2001). Bu dönemden itibaren, MEGG'in terörizmin finansmanının önlenmesi konusunda küresel düzenleyici mekanizma olarak işlev gördüğü söylenebilir.

Dönemin G-7 ülkeleri tarafindan Temmuz 1989'de kurulan MEGG'e, uluslararası kara para aklamayla mücadelede ulusal ve uluslararası eylemleri gözden geçirmek ve uluslararası standartları belirlemek olmak üzere iki ana işlevi yüklenmiştir. MEGG, üye devletlerin Maliye Bakanları ve finansal sektör düzenleyici otoritelerinin (üst kurullar) yetkililerinden oluşan hükümetlerarası bir yapıdır. Hükümetlerarası ilişkilerde devletler, işbirliği yapma veya yapmama konusunda serbesttir ve işbirliği derecesini belirlemektedir (Nugent, 2003: 475). $\mathrm{Bu}$ serbestlik veto, yani bir devletin diğer bir devletin önerisini reddedebilmesi şeklinde uygulanmaktadır. Buna göre, hükümetlerarası ilişkiler devletler açısından herhangi bir egemenlik sınırlaması oluşturmamaktadır.

Buna karş1l1k ulus üstü yapılarda devletler karar verme sorumluluğunun bir kısmını ulus üstü kuruluşlara devretmektedir. Burada, devletler veto hakkına sahip olmadıkları için çoğunluk kararına uygun hareket etmek zorunda kalmakta ve böylece kontrolü kısmen kaybetmektedir. Bu nedenle, ulus üstü yapılar ulusal egemenliğin kısmen kaybına yol açmaktadır (Nugent, 2003: 475). MEGG yapısı içindeyse üye devletler, yapısal olarak ayrı ayrı kontrol ve egemenlik özelliklerini korumaktadır.

MEGG başlangıcından beri, üye ülkelerin Bakanları tarafından verilen karara göre belirli sürelerle faaliyete devam etmektedir. ${ }^{8}$ Bir diğer deyişle, MEGG geçici

8 Bakanlar tarafindan Nisan 2012 ayında yapılan toplantıda MEGG'in 2012-2020 döneminde de faaliyetine devam etmesine karar verilmiştir. MEGG hâlihazırda, 34 ülke ve iki bölgesel örgütten oluşmaktadır: Arjantin, Avustralya, Avusturya, Belçika, Brezilya, Kanada, Çin, Danimarka, Avrupa Komisyonu, Finlandiya, Fransa, Almanya, Yunanistan, 
bir örgütlenme biçimidir. ${ }^{9}$ MEGG'in bütçesi, üye devletler tarafından oluşturulmakta; bütçe katkı işlemleri ise OECD üzerinden yürütülmektedir. Bunun dışında üye devletlerin münferit bütçe katkıları olursa, bu katkılar da genel olarak ülkelerin ulusal gelir durumuna göre yapılmaktadır (www.fatf-gafi.org, 2016).

MEGG, terörizmin finansmanının önlenmesi için iki temel işlev üstlenmiştir: uluslararası standartlar oluşturmak ve hukuki, düzenleyici ve operasyonel önlemlerin uygulanmasını desteklemek. Standartların içeriğine bakıldığında; MEGG'in yasama organının yetki ve sorumluluk alanına giren hukuki, yürütme organının (ve kamu yönetiminin) yetki ve sorumluluk alanına giren düzenleyici, uygulama alanında ise işlevsel bir etkiye sahip olduğu görülmektedir. $\mathrm{Bu}$, MEGG'in kendisini tanımlama biçiminde de görülebilir. MEGG kendisini, ulusal ölçekte yasama ve düzenleyici reformlar için siyasi istek oluşturmak amacıyla çalışan bir politika yapma kuruluşu olarak tanımlamaktadır (www.fatf-gafi.org, 2016). Ulusal politika sürecinin bir aktörü olduğunu ortaya koyan MEGG, hükümetlerarası niteliğinin ötesinde bir siyasal otorite örgütlenmesi olarak ortaya çıkmakta ve devletlerin egemenlik alanları karşısında belirleyici bir konuma yerleşmektedir.

MEGG, tavsiye adı altında uluslararası standart niteliğini taşıyan kurallar geliştirmektedir. Bu standartlar, terörizmin finansmanına karşı, devletler arasında eşgüdüm sağlanması için bir temel oluşturmaktadır. Hedeflenen şey ise, bu standartların evrensel olarak uygulanmasıdır (www.fatf-gafi.org, 2016). MEGG tarafindan oluşturulan uluslararası standartların devletler için bir eşgüdüm temeli olarak nitelenmesi, devletler arasındaki ilişkilerin örgütlenmesinde tarafların

Körfez İşbirliği Konseyi, Hong Kong, İzlanda, Hindistan, İrlanda, İtalya, Japonya, Kore Cumhuriyeti, Lüksemburg, Meksika, Hollanda, Yeni Zelanda, Norveç, Portekiz, Rusya, Singapur, Güney Afrika, İspanya, İsveç, İsviçre, Türkiye, Birleşik Krallık, Amerika Birleşik Devletleri.

9 MEGG, dört organa sahiptir: Genel Kurul (Plenary), Başkan, Sevk İdare Grubu, Sekreterya, Karar organı olan Genel Kurul, yılda üç kez toplanmaktadır. MEGG Başkanı, bu karar mekanizması tarafından ve kendi üyeleri arasından bir yıllığına seçilmektedir. Başkan MEGG icra organıdır. Sevk İdare Grubu ise, MEGG faaliyetlerinin uygulanmasında Başkan'a bağlı olarak görev yapmaktadır. Sekreterya hizmeti ise, OECD tarafindan sağlanmaktadır. 


\section{A. BARBAK.}

belirleyici olduğu bir yapıdan ziyade MEGG'in belirlediği ilişki kurma biçiminin istendiğini göstermektedir. Özellikle MEGG'in işlevlerine bakıldığında bu durumu daha kolayl1kla görmek mümkündür (www.fatf-gafi.org, 2016):

- Başta üye devletler olmak üzere diğer devletlerin uluslararas1 standartlara uygunluk durumlarını izlemek,

- Terörizmin finansmanı tekniklerini gözden geçirmek,

- Uygun önlemlerin küresel olarak benimsenmesini ve uygulanmasinı desteklemek,

- Diğer uluslararası paydaşlar ile işbirliği içerisinde, uluslararası finansal sistemi korumak için ulusal seviyede güvenlik açıklarını belirlemek.

Kerwer ve Huelsse (2011: 51), MEGG'in standart koyucu niteliğinin ötesinde gizli güç haline geldiğini, gönüllülükten ziyade zorlayıcı yanının öne çıktığını ve böylece MEGG gibi standart koyucuların küresel otoriteler olarak işlediğini belirtmektedir. Turner (2014: 548) ise, MEGG'in tavsiye sistemini ve standart koyuculuğunu yumuşak hukuk olarak tanımlamakta ve uluslararası anlaşmalar yanında yumuşak hukukun finansal düzenlemelerde küresel uyumu artırdığını savunmaktadır. $\mathrm{Bu}$ iki sav, küresel yönetişimde öngörülen hukuk sistemi ile örgütlenme ve otorite uygulama biçimine işaret etmektedir.

Bu çerçevede, MEGG sıklıkla uluslararası finansal sistemin bütünlüğü vurgusu yapmaktadır. MEGG açısından terörizmin finansmanı, uluslararası finansal sistemin bütünlüğü için bir tehdit niteliğindedir (www.fatf-gafi.org, 2016). Terörizmin finansmanının önlenmesine yönelik küresel politika ve yönetişim açısından istenen şeyin ise, ulusal finansal sistemlerin küresel yönetişime uyarlanmaları ve uluslararası kontrol mekanizmasına dâhil olmaları olduğu açıkça görülmektedir.

\subsection{2. Üyelik: Küresel Yönetişime Katılım}

MEGG'in terörizmin finansmanının önlenmesinde kurulacak küresel yönetişime uyum için ilk tavsiyesi, BM’nin terörizmin finansmanının önlenmesine 
ilişkin uluslararası sözleşmenin devletlerin yasama organları tarafindan onaylanmasıdır. Bu ilk tavsiye, doğrudan devletin yasama otoritesinin kullanımına ilişkindir. Bunun küresel yönetişime katılım ve küresel politikaya uyum için temel koşul olması, tavsiye niteliğinin ötesine geçmektedir.

MEGG, küresel yönetişim yapısını iki bileşen üzerinden kurmaktadır. İlk bileşen, doğrudan MEGG'in kendi üyeleridir. Bunun dışında, MEGG üyelerinin oluşturduğu coğrafyanın dışında faaliyet gösteren bölgesel MEGG benzeri yapılar da vardır. Bu yapılar bölgesel ölçekte örgütlenmiştir. Mevcut 36 üyesine ilave olarak, kendisi gibi işleve sahip sekiz bölgesel görev gücü ${ }^{10}$ ile bağlantısı olan MEGG, terörizmin finansmanına karşı küresel ă̆ içerisinde merkezi konumdadır ve bu bölgeleri küresel politika ağı içerisinde kontrol etmektedir. Bu bölgelerde MEGG'in standartları esas alınmakta; bilgi akışı bölgelerden MEGG merkezine doğru olmaktadır (FATF, 2015b).

MEGG, üyelerini belirli koşullarla kabul etmektedir. Koşullar, belirli standartlara işaret etmekte ve üyelik için adayın bu standartlara sahip olması istenmektedir. Bu anlamda, üyelik küresel yönetişime katılmak için uyum sağlama aracı niteliğindedir. ${ }^{11}$ MEGG kendisine özgü bir üyelik politikası ilan etmiştir. Üyelik süreci (Tablo-2), adaylık süreci ve üyelik süreci olmak üzere iki aşamadan oluşmaktadır (www.fatf-gafi.org, 2016). Statü olarak ilk aşamada gözlemcilik, sonrasında ise $\ddot{u} y e l i k$ verilmektedir. ${ }^{12}$

\footnotetext{
${ }^{10}$ Bunların kısaltmaları şöyledir: APG, CFATF, EAG, ESAAMLG, GAFILAT, GIABA, MENAFATF, MONEYVAL.

11 Hindistan Hükümeti, terörizmin finansmanına karşı ulusal kapasiteyi artıracağ gerekçesiyle MEGG Başkanından üyelik talep etmiştir. Hindistan Maliye Bakanı, MEGG'in Hindistan'ı stratejik olarak önemli tanımladığını belirtmiştir. Hindistan Maliye Bakanı'na göre, MEGG üyeliği finansal kurumların örgütlü suçlara karşı hassasiyetini ortadan kaldiracak ve terörist parasının takip edilmesine yönelik kapasite oluşturacaktır. Hindistan'ın üyelik süreci için bkz. http://www.finmin.nic.in/press_room/2011/Press_ Release_FATF_25022011.pdf, (10.06.2016).

12 MEGG üyeleri yanında gözlemci statüsünde olan ülkeler ve uluslararası örgütler de vardır. Bunlar için bkz. http://www.fatf-gafi.org/about/membersandobservers/\#d.en.3147, (10.01.2016).
} 


\section{A. BARBAK.}

Tablo-2'de belirtildiği gibi, MEGG'e üye olarak seçilecek ülkenin her şeyden önce stratejik önem sahibi olması istenmektedir. ${ }^{13}$ Burada stratejik önemin nasıl belirleneceğine bakılmalıdır. Gayrisafi milli hâsıla ve finansal sistemin büyüklüğü o ülkenin küresel gelir toplamı ve finansal büyüklük içerisindeki payı hakkında bilgi verirken nüfus, her türlü varlık ve kaynaklarının kişi başına dağılımı hakkında fikir vermektedir. Niteliksel göstergelerin de ülkenin küreselleşme derecesini gösterdiği söylenebilir.

Tablo 2. MEGG Üyelik Süreci

\begin{tabular}{|c|c|c|}
\hline Aşama & Ölçüt & Yöntem \\
\hline $\begin{array}{l}\text { Adaylık } \\
\text { Süreci }\end{array}$ & Stratejik önem & $\begin{array}{l}\text { Niceliksel Göstergeler: Gayrisafi Yurtiçi } \\
\text { Hâsıla büyüklüğü, bankacılık, sigorta ve } \\
\text { menkul kıymetler sektörlerinin büyüklüğü, } \\
\text { nüfus. } \\
\text { Niteliksel Göstergeler: Küresel finansal } \\
\text { sisteme etki, MEGG benzeri yapılara aktif } \\
\text { katılım, terörizmin önlenmesi çabalarına } \\
\text { bağlılık seviyesi, terörizmin finansmanı } \\
\text { riskleri ve risklerle mücadele çabaları. } \\
\text { Diğer Göstergeler: Finansal sektör } \\
\text { standartlarına bağlılık seviyesi, ilgili diğer } \\
\text { uluslararası örgütlere katılım. }\end{array}$ \\
\hline \multirow[t]{2}{*}{$\begin{array}{l}\text { Üyelik } \\
\text { Süreci }\end{array}$} & $\begin{array}{l}\text { Birinci Adım: } \\
\text { Ülkeyle ilişki, gözlemcilik } \\
\text { statüsü }\end{array}$ & $\begin{array}{l}\text { Siyasal Taahhüt: MEGG tavsiyeleri ve } \\
\text { değerlendirme metodolojisi kabulü, } \\
\text { müşterek değerlendirme anlaşması, MEGG } \\
\text { faaliyetlerine destek ve katıllım. } \\
\text { MEGG Ülke Ziyareti: Yazılı taahhüttün } \\
\text { yerinde incelenmesi, teknik uyumun } \\
\text { belirlenmesi, MEGG rejimine ilişkin } \\
\text { tavsiyelerin belirlenmesi, ilgili devletin } \\
\text { MEGG Genel Kuruluna gözlemci olarak } \\
\text { davet edilip edilemeyeceği kararı. }\end{array}$ \\
\hline & $\begin{array}{l}\text { İkinci Adım: } \\
\text { Müşterek değerlendirme, }\end{array}$ & $\begin{array}{l}\text { Müșterek Değerlendirme Raporu (Uygun): } \\
\text { Gözlemci statüsü verilmesi, MEGG İletişim }\end{array}$ \\
\hline
\end{tabular}

${ }^{13}$ MEGG Başkanı, Haziran 2015 ayında Suudi Arabistan'1, MEGG üyesi olmaya davet etmiştir. Davet, MEGG heyetinin Suudi Arabistan'ı ziyaretinden sonra gelmiştir. MEGG Başkanı, Suudi Arabistan'ın dünya ekonomisinde stratejik olarak önemli bir ülke olduğunu; terörizmin finansmanının önlenmesi konusunda önemli adımlar attığını ve bu nedenlerle üye olmasının kendisi için de önemli olduğunu belirtmiş̧tir. Bu kapsamda, Suudi Arabistan'ın üye olmak için MEGG Genel Kurulu'na başvuru yapması ve bir finansal sisteminin ayrıntılı bir değerlendirmeden geçmesi gerektiği ifade etmiştir. Bkz. http://www.argaam.com/en/article/articledetail/id/380050, (14.06.2016). 


\begin{tabular}{|l|l|l|}
\hline eylem planı ve üyelik. & $\begin{array}{l}\text { Grubu tarafından ülkenin uyum faaliyetleri, } \\
\text { üyelik. } \\
\text { Müșterek Değerlendirme Raporu (Kısmen }\end{array}$ \\
$\begin{array}{l}\text { Uygun): Siyasal süreli taahhüt, ülke eylem } \\
\text { planı, eylem planı uygulanmasının } \\
\text { izlenmesi. }\end{array}$ \\
\hline
\end{tabular}

Ayrıca bu göstergeler, MEGG ile devletler arasında öngörülen ilişki biçimine ve küresel yönetişim bağlamında devletlere ilişkin yeni bir ayrıma işaret etmektedir. $\mathrm{Bu}$ göstergeler iki başlık altında toplanabilir: stratejik önem, küresel yönetişime katılım. Dolayısıyla, kısaca şöyle denilebilir: Stratejik önemi olmayan ve küresel yönetişim ile bütünleşmemiş devletler üye olamazlar. Bu göstergeler, devletlerin yeni bir tür sınıflandırması niteliğindedir. Gelişmiş ve gelişmekte olan ya da az gelişmiş ülkeler gibi ayrımlardan sonra, küresel yönetişimde stratejik olan ya da olmayan ya da nispeten az olan; küresel yönetişime katılım sağlamış olanla nispeten daha az sağlamış olan ya da uyum sağlamış olan ile olmayan şeklinde yeni bir ayrım ortaya çıkmıştır.

Üyelikte Müssterek Değerlendirme sürecinin belirleyici olduğu görülmektedir. Müşterek değerlendirme, devletlerin ya da terörizmin finansmanının önlenmesine yönelik küresel politika ağına katılmak isteyen üyelerin küresel politika ve standartlara uyum derecesini belirlemeye yöneliktir. Müşterek Değerlendirme Raporu, bir devletin terörizmin finansmanına karşı ulusal mevzuatındaki boşlukları tanımlamakta ve öneriler getirmektedir. MEGG, Raporun ana bulgularını ve genel değerlendirmesini yayımlamakta ve böylece hangi devletin uluslararası standartlara ne derece uyduğunu ve hangi konularda sorunları olduğunu diğerlerine göstermektedir. Eğer bir üye devlet kısmen uyumlu bulunursa, MEGG bu devletin uyum boşluklarını gidermeye dönük eylemlerini kontrol etmeye devam etmektedir. MEGG'in sıradan üyeleri, her birkaç yılda bir Müşterek Değerlendirme sürecinden geçmektedir (www.fatf-gafi.org, 2016).

\subsubsection{Yaptırım: Küresel Yönetişim ve Politikaya Zorlayıcı Uyum}

MEGG'in, terörizmin finansmanına karşı politikaya uyum sağlamayan üyelere karş1 resmi bir yaptırım gücü yoktur. Ancak küresel yönetişim ve politika ağlarının yapısından kaynaklanan zorlayıcı bir uyum gücüne sahip olduğu ileri sürülebilir. 


\section{A. BARBAK.}

MEGG'in devletlerle kurduğu ilişki biçimine (www.fatf-gafi.org, 2016) bakılarak zorlayıcı uyum mekanizmalarını çıkarmak mümkündür (Tablo-3).

Tablo 3. MEGG'in Zorlayıcı Uyum Mekanizmaları

\begin{tabular}{|c|c|c|c|c|}
\hline \multicolumn{2}{|r|}{$\begin{array}{l}\text { Zorlayıcı Uyum } \\
\text { Mekanizması }\end{array}$} & Yöntem & Araç & Amaç \\
\hline \multirow{3}{*}{ 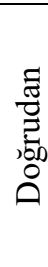 } & $\begin{array}{c}\text { Düzenli } \\
\text { değerlendirme }\end{array}$ & $\begin{array}{c}\text { Standartlara uyum } \\
\text { kontrolü, izleme, } \\
\text { sapmaların giderilmesi }\end{array}$ & $\begin{array}{l}\text { Değerlendirme } \\
\text { raporları }\end{array}$ & Yakınsama \\
\hline & \multirow[b]{2}{*}{ Üyelik koşulları } & \multirow{2}{*}{$\begin{array}{l}\text { Uyum olmaması } \\
\text { durumunda üyeliğin } \\
\text { askıya alınması }\end{array}$} & Koşullu üyelik & Uyarlama \\
\hline & & & $\begin{array}{c}\text { Düzenli } \\
\text { değerlendirmeler }\end{array}$ & Ceza \\
\hline \multirow{3}{*}{ 紊| } & \multirow{2}{*}{ Teşhir etme } & $\begin{array}{l}\text { Değerlendirme } \\
\text { sonuçlarının } \\
\text { yayımlanması }\end{array}$ & $\begin{array}{c}\text { Müşsterek } \\
\text { değerlendirme } \\
\text { raporu }\end{array}$ & \multirow{2}{*}{ Caydırıcılık } \\
\hline & & $\begin{array}{l}\text { Uyumlu sağlamayan } \\
\text { ülkelerin yayımlanması }\end{array}$ & $\begin{array}{c}\text { İssbirliği Yapmayan } \\
\text { Ülke veya Bölgeler } \\
\text { (NCCT) Listesi }\end{array}$ & \\
\hline & $\begin{array}{c}\text { Uluslararası } \\
\text { örgütler ile olan } \\
\text { ilişkiler }\end{array}$ & $\begin{array}{c}\text { Uluslararası mali } \\
\text { kuruluşların ülke } \\
\text { raporlarını izlemesi ve } \\
\text { anlaşma süreçlerinde } \\
\text { ölçüt ya da koşul olarak } \\
\text { kullanması. }\end{array}$ & $\begin{array}{c}\text { Varlıkların } \\
\text { dondurulması, } \\
\text { varlıklara el } \\
\text { konulması, finansal } \\
\text { ilişkinin kesilmesi }\end{array}$ & $\begin{array}{c}\text { Kaynak } \\
\text { bağımlılığı }\end{array}$ \\
\hline
\end{tabular}

Tablo-3’te gösterilen mekanizmalar, doğrudan ve dolaylı olmak üzere iki grupta toplanmıştır. Burada doğrudan zorlayıcı uyum mekanizmaları MEGG-Devlet ilişkisinde görülen zorlayıcı uyum mekanizmalarına işaret ederken dolaylı uyum mekanizmaları, küresel yönetişim yapılarının devletler üzerindeki etkisini kullanarak bu devletlerin terörizmin finansmanının önlenmesi politikasına uyumunu sağlamaya çalışmaktadır. ${ }^{14}$ Tablo-3'teki zorlayıcı uyum mekanizmaları, küresel yönetişimin de tanımlayıcı özelliklerine işaret etmektedir.

\footnotetext{
${ }^{14}$ Örneğin MEGG, Şubat 2008 ayında, terörizmin finansmanına karşı sisteminde eksiklikler olduğu gerekçesiyle Pakistan'1 eleştirmiş ve Pakistan'ın ulusal yasal çerçevesindeki eksikliklerin uluslararası finansal sistemde hassasiyet oluşturduğunu açıklamıştır. MEGG, Pakistan'ın terörizmin finansmanına karşı kanunlarını uluslararası standartlara uygun hale getirmesini ve Asya Pasifik Grubuyla yakın çalışmasını istemiştir. Bkz. http://www.idsa.in/idsastrategiccomments/PakistanCastigatedforDeficienciesinCounterTerr oristFinancingRegime_SKSaini_170308,(14.06.2015).
} 
Zorlayıcı uyum denildiğinde, öncelikle Tablo-3'te gösterilen amaçlar üzerinde durulmalıdır. Çünkü zorlayıcı uyum yakınsama, uyarlama, cezalandırma, caydırıcılık ve kaynak bağımlılı̆̆ boyutlarıyla ortaya çıkmaktadır. ${ }^{15}$ Yakınsama, politika amaçlarında, araçlarında, sürecinde ve sonuçlarında giderek artan bir benzeşme anlamına gelirken (Bennett, 1991), uyarlama küresel finans piyasaları ile bütünleşme için devletlerin finansal sistemlerinin regülasyonunu/deregülasyonunu ifade etmektedir. Cezalandırma ve caydırıcılık, birlikte ele alınmalıdır. Ceza, yaptırımın bir uygulama biçimidir. Caydırıcılık ise, cezalandırma yaptırımı öne sürülerek uyumun önceden sağlanmasına yöneliktir. $\mathrm{Bu}$ anlamda, caydırıcılık cezalandırmadan önceki aşamayı temsil etmektedir. Kaynak bağımlılığı ise, devletlerin uluslararası finansal sisteme bağ(1m)l1lı̆̆ını ve bu sistemden çıkmamak için bu sistemin kurumlarının belirlediği kurallara uyma zorunluluğunu ifade etmektedir. Bir diğer deyişle, bir devletin kaynaklarını kontrol altında tutan bir uluslararası finansal kuruluşun, o devleti siyasal ve ekonomik olarak kontrol etmesi olasılığı artacaktır (Pfeffer ve Salancik, 1978; Pfeffer ve Salancik, 2003).

MEGG üzerinden yapılan incelemeye göre, küresel yönetişim ile küresel yönetişime ve politikaya uyumu sağlamada kullanılan mekanizmaların ilişkisi Şekil-1'deki gibi gösterilebilir.

Şekil-1'e göre, düzenleyici mekanizma olarak işleyen MEGG, terörizmin finansmanına karşı küresel yönetişim için yakınsama, uyarlama (yapısal ve işlevsel), cezalandırma, caydırıcılık ve kaynak bă̆ımlılı̆̆ sağlamaya çalışmaktadır. Bu amaçlara ulaşmak içinse, küresel yönetişim için zorlayıcı uyum mekanizmaları olarak üyelik koşulları, düzenli değerlendirme, teşhir etme ve uluslararası örgütlerle ilişkileri kullanmaktadır. Küresel yönetişim ise, başta

\footnotetext{
15 Örneğin, nükleer konusunda varılan anlaşma sonucunda İran'a yönelik yaptırımların hafifleyeceğini belirten MEGG, buna rağmen Şubat 2016 ayı içerisinde üye devletlerini, bankalarını İran ile iş yapma konusundaki riskler konusunda uyarmasını istemiştir. BM, Avrupa Birliği ve ABD tarafından yaptırımların hafifletilmesi kararının hemen ardından MEGG, İran’ı yüksek riskli ülke statüsünde tutmaya devam etmiştir. Uluslararası Para Fonu da, İran'ın MEGG'in terörizmin finansmanına karşı standartlarını uygulaması istemiştir. Bkz. http://breakingenergy.com/2016/03/02/irans-long-road-to-reintegratingwith-the-world-financial-system/, (14.06.2016).
} 


\section{A. BARBAK.}

politika yakınsaması olmak üzere, devletlerin yapısal ve işlevsel uyarlanması, ıraksama meydana geldiğinde cezalandırılması veya caydırılması; temelde de devletlerin uluslararası örgütlere kaynak bağımlılığının oluşturulması amaçlarına ulaşmayı öngörerek bu döngüyü sürdürmektedir.

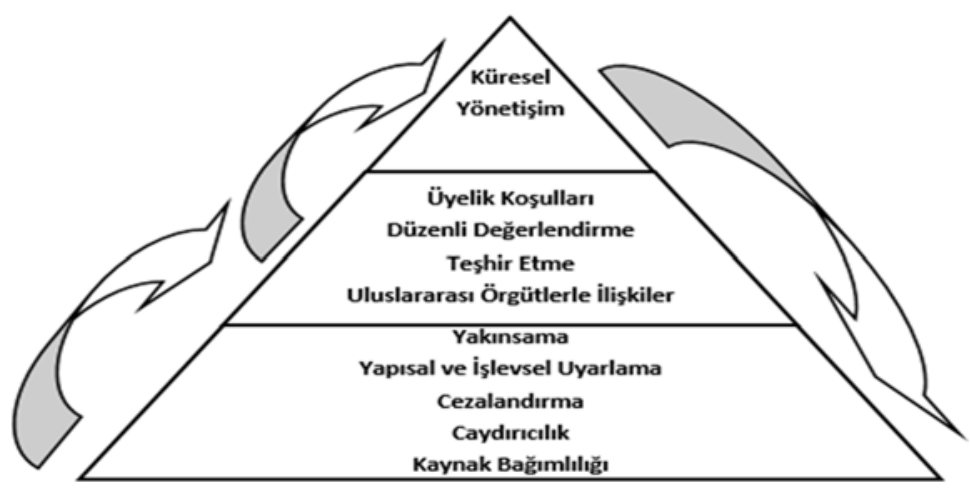

Şekil 1. Küresel Yönetişim-Zorlayıcı Uyum İlişkisi

Zorlayıcı uyum mekanizmalarının en etkili olduğu alanın, ülkelerin uluslararası örgütler ile olan ilişkileri olduğu söylenebilir. Bu kapsamda, IMF ve DB, 2001 yılından itibaren MEGG ile birlikte çalışmaya başlamış (IMF ve World Bank, 2004) ve ülkeler ile ilişkilerinde MEGG standartlarına uyumu bir ölçüt ve ön koşul olarak kullanmaya başlamıştır. Buna ilave olarak IMF ve DB, MEGG yöntemini kullanarak ülkelerin MEGG standartlarına uyumunu incelemek için müşterek ülke değerlendirmeleri yapmaktadır (IMF, 2001).

IMF ve World Bank (2004), genel olarak yüksek ve orta gelir sahibi ülkelerde uluslararas1 standartlara uyumun düşük gelirli ülkelere göre daha yüksek oranda olduğunu; terörizmin finansmanına yönelik küresel yönetişimde ise temel sorun alanının finansal bilgilerin gizliliği ve sınırlı paylaşımı nedenleriyle eşgüdüm eksiklikleri olduğunu belirtmişlerdir. MEGG'e ilave olarak, IMF ve World Bank (2004) devletlerin uyum sağlaması gereken koşulları şöyle ortaya koymuştur:

- BM sözleşmelerinin devletler tarafından imzalanması ve onaylanması,

- Terörizmin finansmanının iç hukukta bir suç olarak tanımlanması,

- Terörist varlıkların dondurulması ve bunlara el konulması, 
- Terörizme ilişkin şüpheli finansal işlemlerin ulusal ve uluslararası kuruluşlara rapor edilmesi,

- Uluslararası işbirliğinin artırılması,

- Para transferi işlemlerinin izlenmesi.

Yukarıda belirtilen sorun alanlarının MEGG standartları ile aynı olduğu görülmektedir. Bu durum bir taraftan küresel yönetişim çerçevesinde bir politika yakınsaması ortaya çıktığını gösterirken diğer taraftan da küresel yönetişime uyum için zorlayıcı bir mekanizma işlevi gördüğünü söylemek mümkündür.

\subsubsection{Küresel Yönetişim ve MEGG: Devletlerle İlişki Kurma Biçimi ve}

\section{Özellikler}

MEGG'in özelliklerine bakıldığında, terörizmin finansmanına karşı küresel yönetişim ve politika ağı içerisinde diğer aktörlerle ilişki kurma biçimini görmek mümkündür. $\mathrm{Bu}$ ilişki kurma biçimine ilişkin bileşenler, Tablo-4 ve Tablo-5'te gösterilmiştir. $\mathrm{Bu}$ bileşenlere bakılarak MEGG'in kendisini devletler karşısında nasıl konumlandırdığ 1 tespit edilebilir. MEGG'in kendisini konumlandırma biçiminden, devletlerin bu küresel politikaya uyumunun ve kendi politikalarının oluşumunun nasıl gerçekleştiğini de görmek mümkündür.

Tablo 4. MEGG’in Devletlerle İlişki Kurma Biçimi

\begin{tabular}{|c|c|c|c|}
\hline Bileşen & Mekanizma & İşlev & Yöntem \\
\hline \multirow{2}{*}{$\begin{array}{c}\text { Küresel } \\
\text { Düzenleyici } \\
\text { Mekanizmanın } \\
\text { Yönetimi }\end{array}$} & Genel Kurul & $\begin{array}{c}\text { Kontrol, } \\
\text { değerlendirme, } \\
\text { statü verilmesi }\end{array}$ & $\begin{array}{l}\text { Ülke ziyareti, müşterek } \\
\text { değerlendirme, genel kurul } \\
\text { kararı }\end{array}$ \\
\hline & Bütçe katkısı & $\begin{array}{l}\text { Masrafların } \\
\text { karşılanması }\end{array}$ & Üyelik ücreti \\
\hline \multirow{2}{*}{$\begin{array}{l}\text { Küresel } \\
\text { Yönetişime } \\
\text { Katılım }\end{array}$} & Üyeli & $\begin{array}{c}\text { Üyelik ko } \\
\text { yoluyla }\end{array}$ & İzleme, değerlendirme, seçim \\
\hline & $\begin{array}{l}\text { Uyum sürecinin } \\
\text { izlenmesi }\end{array}$ & İzleme ve takip & $\begin{array}{l}\text { Sürekli iletişim (İletişim } \\
\text { Grubu), düzenli } \\
\text { değerlendirme }\end{array}$ \\
\hline \multirow{4}{*}{$\begin{array}{c}\text { Küresel } \\
\text { Yönetişim } \\
\text { Politika Süreci }\end{array}$} & $1 a v s$ & Uyarlama & Uluslararası standartlar \\
\hline & Ĕgit & Yönlendirme & Rehberler \\
\hline & $\begin{array}{c}\text { Müşterek } \\
\text { Değerlendirme }\end{array}$ & $\begin{array}{c}\text { Uyum derecesi } \\
\text { belirleme }\end{array}$ & s değerlendirmesi \\
\hline & Raporlama & $\begin{array}{c}\text { Geri besleme ve } \\
\text { erken uyarı }\end{array}$ & $\begin{array}{c}\text { Değerlendirme sonuçlarının } \\
\text { paylaşımı }\end{array}$ \\
\hline
\end{tabular}




\section{A. BARBAK.}

Tablo-4'te gösterildiği üzere, MEGG devletlerle çeşitli şekillerde ilişki kurmaktadır. Burada Genel Kurul kararlarının niteliği öne çıkmaktadır. Çünkü hükümetlerarası bir mekanizma olarak devletler karşısında statü verme yetkisine sahip olması, MEGG'in devletler üstünde bir otorite kullanımına işaret etmektedir. $\mathrm{Bu}$ durum, küresel yönetişimin bir yönüne işaret etmektedir. Bu çerçevede, küresel yönetişim bir koşullu üyelik sistemi olarak da nitelenebilir.

MEGG'in devletlerle ilişki kurma biçimine bakılarak (Tablo-1 ve Tablo-4 karşılaştırılarak) genel olarak küresel yönetişimde devletlerle öngörülen ilişki kurma biçimleri hakkında da çıkarımlarda bulunulabilir.

Tablo 5. Küresel Yönetişim ve MEGG’in Tanımlayıcı Özellikleri

\begin{tabular}{|c|c|c|}
\hline \multicolumn{2}{|c|}{$\begin{array}{l}\text { Tanımlayıcı Özellik } \\
\text { (Küresel Yönetişim) }\end{array}$} & $\begin{array}{l}\text { Tanımlayıcı Özellikleri } \\
\text { (MEGG) }\end{array}$ \\
\hline \multirow{7}{*}{ Yapisal } & Otorite Örgütlenmesi & Hükümetlerarası, geçici \\
\hline & $\begin{array}{l}\text { Resmi ve Resmi Olmayan } \\
\text { Unsurlardan Oluşan } \\
\text { Örgütlenme }\end{array}$ & $\begin{array}{l}\text { Siyasi ve idari personel, OECD den yer, bütçe } \\
\text { ve sekreterya, tam biçimsel ve kurumsal } \\
\text { olmayan yap1 }\end{array}$ \\
\hline & Yatay farklılaşma & $\begin{array}{l}\text { Devlet-devlet diş1 ve finans-güvenlik aktörleri } \\
\text { arasında otorite bölünmesi }\end{array}$ \\
\hline & Tematik örgütlenme & Terörizmin finansmanının önlenmesi \\
\hline & Ă̆ tipi örgütlenme & $\begin{array}{l}\text { Devlet ve devlet dişı aktörlerle işbirliği, } \\
\text { eşgüdüm, uzlaşma ve uyum sağlama }\end{array}$ \\
\hline & Çok kademeli yönetişim & Ulus altı, ulusal ve ulus üstü yapılarla işbirliği \\
\hline & Esnek örgütlenme & $\begin{array}{l}\text { Değerlendirme metodolojisi ve standartların } \\
\text { güncellenmesi }\end{array}$ \\
\hline \multirow{3}{*}{ İşlevsel } & $\begin{array}{c}\text { Devlet diş1 siyasal otorite } \\
\text { mekanizması }\end{array}$ & $\begin{array}{l}\text { Küresel düzenleyicilik, zorlayıc1 uyum, } \\
\text { kolektif otorite }\end{array}$ \\
\hline & $\begin{array}{c}\text { Politika uyum } \\
\text { mekanizması }\end{array}$ & $\begin{array}{l}\text { Doğrudan ve dolaylı zorlayıcı uyum } \\
\text { mekanizmaları, küresel düzenleyicilik }\end{array}$ \\
\hline & Kontrol mekanizmas1 & $\begin{array}{l}\text { Kurallar sistemi, standartlar, koşullar, politika } \\
\text { tasarımı, izleme, değerlendirme }\end{array}$ \\
\hline
\end{tabular}

Tablo-5'e göre, MEGG'in küresel yönetişimin tanımlayıcı özelliklerini taşıdığı görülmektedir. Burada zamana bağlı olarak değişecek olan şey ise, başta MEGG yapıs1 olmak üzere MEGG’in küresel yönetişim yapıs1 içerisindeki statüsü ve küresel yönetişimin kendisinin kurumlaşma derecesi olarak ileri sürülebilir. Çünkü halen uluslararası örgütler gibi biçimsel bir yapıya sahip olmayan MEGG, küresel yönetişimde önde gelen uluslararası örgütlerin (BM, OECD, IMF, DB) desteğiyle 
işlev göstermektedir. Yani, bu durumdaki zaman içerisindeki değişim kurumlaşma derecesini de değiştirecektir.

\section{SONUÇ}

Uluslararas1 terörizmin finansmanının önlenmesi, 1990'lardan itibaren gelişmeye başlamış küresel bir politikadır. Bu kapsamda, özellikle 2000'li y1llarda devletlerin terörizmin finansmanının önlenmesine ilişkin politika süreçlerini açıklayabilmek için bu küresel yönetişimin yapısının, işlevlerinin ve devletlerle ilişki kurma biçiminin incelemelerde göz önünde bulundurulması gerekmektedir. Politika süreci bağlamında ortaya çıkan durum, siyasal otoritenin devlet dışında örgütlenme çabasıdır. Siyasal otorite, devlet ölçeğinde ortaya çıkan ve temsili demokratik sistemden temelini alan bir otorite örgütlenmesidir. Siyasal otorite; anayasa ve yasalar ile yasama, yürütme ve yargı organlarında somutlaşan meşru iktidarı temsil etmektedir. Bu yönüyle, devlet ölçeğinde politika sürecini yürüten; kararlar alan, bu kararları uygulayan ve uygulamayı değerlendiren kurumları ifade etmektedir. Siyasal otoritenin devlet dışına taşınması ise, politika sürecinin belirli derecede devlet dışındaki bir ölçeğe taşınması anlamına gelmektedir. Bu ölçek günümüzde küresel ölçektir.

Küresel yönetişim söz konusu olduğunda en sık karşılaşılan kavramlar eşgüdüm, işbirliği, uyum kavramlarıdır. Bunlar aynı zamanda küresel yönetişimin temel siyasal ve yönetsel sorunlarına işaret etmektedir. Eşgüdüm, küresel yönetişim içerisindeki aktörlerin faaliyetlerini birbirlerini bilgilendirerek yapmasını ifade ederken işbirliği, küresel politika için birlikte çalışmak anlamına gelmektedir. Uyum ise, küresel yönetişim açısından belki de en tartışmalı kavramdır. Çünkü uyum, küresel yönetişim-devlet ilişkisinde devletin egemenliğine ilişkin kaygılara çok yakın bir kavramdır. Eşgüdüm ve işbirliği, küresel yönetişim aktörleri arasında yatay bir ilişkiyi temsil ederken uyum, küresel yönetişim ile devlet arasında dikey (hiyerarşik) bir ilişki kurmaktadır. Çünkü uyum, devletlerin küresel politika ă̆l ve yönetişime yapısal ve işlevsel olarak bütünleşmesi durumudur. Küresel yönetişim bağlamında uyum, devletlerin egemenliğinin sınırlandığına ilişkin tartışmalarda üzerinde durulması gereken temel kavramlardan birisi olarak nitelenebilir. 


\section{A. BARBAK.}

MEGG, terörizmin finansmanına karşı politikanın uluslararası alanda uygulamaya geçirilmesi ve takip edilmesi açısından bir operasyonel mekanizma niteliğindedir. BM tarafindan 1990'lı yıllarda terörizmin finansmanına karşı üye devletlerin işbirliğinin sağlanması yeterli derecede olmadığından bunu sağlayacak bir mekanizmaya ihtiyaç duyulduğu açıktır. Özellikle, BM'nin bu konuda uygulamaya dönük bir biriminin olmaması, politikanın uygulamaya geçirilmesi açısından başlıca sorun olarak görülebilir. MEGG, 2001 yılından itibaren, terörizmin finansmanına karşı küresel politika ve yönetişim yapısında çeşitli işlevleri yerine getiren bir yapı olarak politika ağının merkezine yerleşmiştir. Buna göre MEGG'in özellikleri, alanyazında küresel yönetişimi tanımlamak için kullanılan tanımlayıcı özellikler ile örtüşmektedir.

Bu bağlamda MEGG'in işlevsel özelliklerini ortaya koymak gerekmektedir. MEGG, öncelikle terörizmin finansmanına karşı küresel yönetişimde düzenleyici mekanizma olarak işlev göstermektedir. Düzenleyicilik işlevini, finansal alana ilişkin uluslararası standartlar koyarak ve devlet politikalarına ilişkin çerçeve çizerek gerçekleştiren MEGG finansal alanı düzenlemektedir. MEGG ayrıca, bir yaptırım mekanizması olarak da nitelenebilir. Doğrudan ve dolaylı yaptırım araçlarına sahip olan MEGG, özellikle diğer uluslararası örgütler ile olan işbirliği sayesinde yaptırım gücünü ve alanını genişletmektedir.

MEGG'in bir diğer özelliği, uyum sağlayıcı mekanizma olarak işlev görmesidir. MEGG, hem üyelerinin hem de üyelik başvurusu yapan ya da yapmayan devletlerin, kendisinin belirlediği standartlara uymasını beklemektedir. Böylece küresel yönetişim ve politikanın uygulanabilmesi için daha büyük bir finansal alanın ve coğrafyanın kontrol edilmesi mümkün hale gelmektedir. MEGG ayrıca, devletlerin terörizmin finansmanına yönelik politika süreçlerini takip eden bir kontrol mekanizması olarak işlev görmektedir. Devletleri izleme ve değerlendirme süreçleri ile takip ve kontrol eden MEGG, kamuya açık raporlama yaparak doğrudan ve dolaylı kontrol alanını genişletmektedir. 


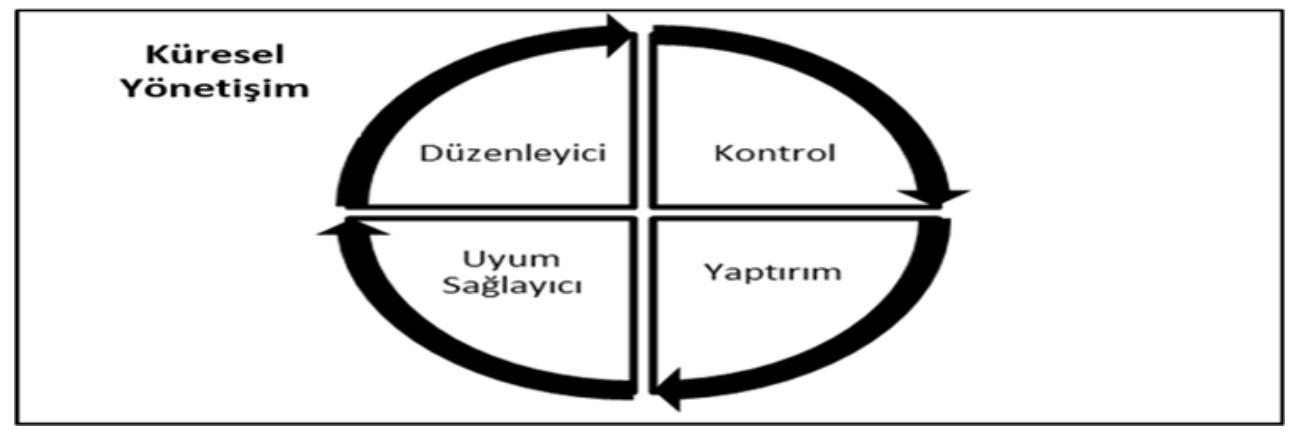

Şekil 2. MEGG'in İşlevsel Özellikleri (Döngüsel)

Şekil-2'de gösterildiği gibi, MEGG'in işlevsel özellikleri bir döngüsel süreç olarak ortaya çıkmaktadır. Düzenleyicilik işlevi kapsamında geliştirmiş olduğu standartlar ve politika önerileri sayesinde bir kontrol mekanizması işlevi kazanan MEGG, kontrol işlevi aracılığıyla devletlerin finansal alanı üzerinde bir yaptırım gücü kazanmaktadır. MEGG'e yaptırım mekanizması niteliği kazandıran bu durum ise, devletleri terörizmin finansmanına yönelik küresel politika ve yönetişime uyum sağlamaya zorlamaktadır. Ortaya çıkan uyum ise, düzenleyicilik işlevinden beklenen sonuca ulaşılması hatta düzenleyicilik işlevinin daha da güçlenmesi olarak değerlendirilebilir.

Terörizmin finansmanına karşı küresel yönetişimin geleceğine yönelik bir öngörü yapılmak istenirse, üzerinde durulması gereken ilk mesele küresel yönetişimin kurumsallaşma ya da kurumlaşma derecesinde ortaya çıkması muhtemel değişimdir. Bir başka deyişle, daha önce bahsedildiği gibi zamanın ve mekânın bir fonksiyonu olan küreselleşme, küresel yönetişim olarak kurumlaşmakta; buna bağlı olarak küresel yönetişimin kurumlaşma derecesi de değişmektedir. Bu kapsamda, MEGG ve MEGG benzeri yapıların gelecekte geçici bir örgütlenme olmaktan çıkarak sürekli bir niteliğe kavuşması beklenmelidir. Bu kurumlaşmanın amacı ise, küresel yönetişim için daha fazla eşgüdüm, uyum ve işbirliği olacaktır. Uluslararası finansal kuruluşların terörizmin finansmanının önlenmesi konusunda daha fazla işlev üstlenmesi sonucunda ise, MEGG'in lağvedilmesinin de gündeme gelmesi beklenebilir. 


\section{A. BARBAK.}

Terörizmin finansmanına yönelik küresel yönetişimin kurumlaşma derecesinin artması sonucunda, MEGG'in işlevsel özelliklerinin daha da güçlenmesi söz konusu olacaktır. Bunun yanı sıra, BM’nin özellikle küresel güvenlik politikaları için başat meşruiyet kaynağı olarak devam edeceği görülmektedir. Ayrıca mevcut durum, MEGG ve MEGG benzeri yapıların oluşturduğu ağ tipi iliş̧i biçiminin korunacağını göstermektedir. $\mathrm{Bu}$ yapıların ă̆ içerisinde daha fazla etkileşim içerisinde olacağ da öngörülebilir. Bu bağlamda, terörizmin finansmanına karşı küresel yönetişim açısından bir ilerleme söz konusudur.

\section{KAYNAKÇA}

BENNETT, C. J. (1991), "What is Policy Convergence and What Causes It?", British Journal of Political Science, 21(2), 215-233.

BÖRZEL, T. A. (1997), "What is so Special About Policy Networks?-An Exploration of the Concept and Its Usefulness in Studying European Governance", European Integration Online Papers (EIoP), 16, http://eiop.or.at/eiop/texte/1997016a.htm, (09.01.2016).

BRONER, F. A., VENTURA, J. (2010), "Rethinking the Effects of Financial Liberalization", NBER Working Paper, 16640, http://www.nber.org/papers/ w16640.pdf, (18.01.2016).

BUZAN, B., WÆVER, O., WILDE, J. (1998), Security: A New Framework for Analysis, Lynne Rienner Publishers, Boulder.

CARAYANNIS, E. G., PIRZADEH, A., POPESCU, D. (2012), Institutional Learning and Knowledge Transfer Across Epistemic Communities, Springer Science+Business Media, USA.

CASTELlS, M. (2008), "The New Public Sphere: Global Civil Society, Communication Networks, and Global Governance", The Annals of the American Academy, 616, 78-93. 
COMMISSION ON GLOBAL GOVERNANCE (1995), Our Global Neighbourhood: The Report of the Commission on Global Governance, Oxford University Press, UK.

COX, R. (1994), "Multilateralism and the Democratization of World Order", 1994 International Symposium on Sources of Innovation in Multilateralism, Switzerland, $1-2$.

DINGWERTH, K., PATTBERG, P. (2006), "Global Governance As a Perspective on World Politics", Global Governance, 12(2), 185-203.

FATF (2015a), "Emerging Terrorist Financing Risks", FATF Report, http://www.fatf-gafi.org/media/fatf/documents/reports/Emerging-TerroristFinancing-Risks.pdf, (25.01.2016).

FATF (2015b), "Terrorist Financing FATF Report to G20 Leaders Actions Being Taken By The FATF", FATF Report, http:/www.fatf-gafi.org/media/fatf/ documents/reports/Terrorist-financing-actions-taken-by-FATF.pdf, (25.01.2016).

FINKELSTEIN, L. S. (1995), "What is Global Governance?”, Global Governance, $1(3), 367-372$.

GIBBS, J. P. (1989), "Conceptualization of Terrorism", American Sociological Review, 54(3), 329-340.

GIDDENS, A. (1998), The Third Way, The Renewal of Democracy, Polity Press, Cambridge.

GIRALDO, J. K., TRINKUNAS, H. A. (2007), "The Political Economy of Terrorism Financing", Terrorism Financing and State Responses: A Comparative Perspective, (Ed. J.K.Giraldo, H.A.Trinkunas), Stanford University Press, USA, 720.

HARVEY, D. (1989), The Condition of Postmodernity: An Enquiry into the Origins of Cultural Change, Blackwell Publishers, Oxford. 


\section{A. BARBAK.}

HETTNE, B. (2002), "In Search of World Order", Global Governance in the 21st Century: Alternative Perspectives on World Order, (Ed. B.Hettne, B.Odén), Almkvist \& Wiksell International, Sweden, 6-25.

HOARE, Q., SMITH, G. N. (1992), Selections from The Prison Notebooks of Antonio Gramsci, International Publishers, USA.

IMF (2001), "Intensified Fund Involvement in Anti-Money Laundering Work and Combating the Financing of Terrorism", Task Force Report, https://www.imf.org/external/np/mae/aml/2001/eng/110501.htm, (25.12.2015).

IMF, WORLD BANK (2004), "Twelve-Month Pilot Program of Anti-Money Laundering and Combating the Financing of Terrorism (AML/CFT) Assessments", Joint Report on the Review of The Pilot Program, http://www.imf.org/external/np/ aml/eng/2004/031604.htm, (27.12.2015).

KAMINSKY, G. L., SCHMUKLER, S. L. (2003), "Short-Run Pain, Long-Run Gain: The Effects of Financial Liberalization", IMF Working Paper, WP/03/34, http://www.imf.org/external/pubs/ft/wp/2003/wp0334.pdf, (26.01.2016).

KEOHANE, R.O. (2002), Global Governance and Democratic Accountability, London School of Economics, UK.

KERWER, D., HUELSSE, R. (2011), "How International Organizations Rule the World: The Case of the Financial Action Task Force on Money Laundering", Journal of International Organizations Studies, 2(1), 50-67.

KRAHMANN, E. (2005), "American Hegemony or Global Governance? Competing Visions of International Security", International Studies Review, 7(4), 531-545.

LAWLESS, M. (2007), “Terrorism: An International Crime", International Journal, 63(1), 139-159.

LEVI, M. (2010), "Combating the Financing of Terrorism: A History and Assessment of the Control of Threat Finance", British Journal of Criminology, 50(4), 650-669. 
NUGENT, N. (2003), Government and Politics of the European Union, Palgrave Macmillan, Basingstoke.

OECD (2001), "FATF Cracks Down on Terrorist Financing", PAC/COM/NEWS, 91, http://www.fatf-gafi.org/dataoecd/45/48/34269864.pdf, (27.12.2015).

OVERBEEK, H. (2004), "Global Governance, Class, Hegemony: A Historical Materialist Perspective", Working Papers Political Science, 2004/01, http://www.fsw.vu.nl/en/Images/Global_Governance,_Class,_Hegemony_A_histor ical_materialist_perspective_tcm250-42721.pdf, (28.12.2015).

PFEFFER, J., SALANCIK, G. R. (1978), The External Control of Organizations: A Resource Dependence Perspective, Haper \& Row, New York.

PFEFFER, J., SALANCIK, G. R. (2003), The External Control of Organizations: A Resource Dependence Perspective, Stanford University Press, USA.

RHODES, R. A. W. (1996), "The New Governance: Governance Without Government”, Political Studies, XLIV, 652-667.

ROSENAU, J. N. (1997), Along the Domestic-Foreign Frontier: Exploring Governance in a Turbulent World, Cambridge University Press, UK.

ROSENAU, J. N. (1999), "Toward an Ontology for Global Governance", Approaches to Global Governance Theory, (Ed. M.Hewson, T.J.Sinclair), State University of New York Press, USA, 287-301.

SCHOLTE, J. A. (2007), "Defining Globalization”, Revista económica de CastillaLa Mancha, 10, 15-63.

SOBACI, M. Z. (2013), "Politika Ağları: Aktörler Arası İlişkiler Üzerinden Kamu Politikasını Anlamak", Kamu Politikası: Kuram ve Uygulama, (Der. M.Yıldız, M.Z.Sobac1), Adres Yayınları, Ankara, 130-147. 


\section{A. BARBAK.}

THE INSTITUTE FOR ECONOMICS AND PEACE (2015), "Global Terrorism Index 2015: Measuring and Understanding The Impact of Terrorism", IEP Report, No. 36, http://economicsandpeace.org/wp-content/uploads/2015/11/GlobalTerrorism-Index-2015.pdf, (06.01.2016).

TURNER, N. W. (2014), "The Financial Action Task Force: International Regulatory Convergence Through Soft Law", New York Law School Law Review, $59,547-559$.

UNITED NATIONS (1994), "Measures to Eliminate International Terrorism", A/RES/49/60, http://www.un.org/ documents/ga/res/49/a49r060.htm, (15.11.2015).

UNITED NATIONS (1996), "Measures to Eliminate International Terrorism", A/RES/51/210, http://www.un.org/documents/ga/res/51/a51r210.htm, (15.11.2015).

UNITED NATIONS (1999), "International Convention for the Suppression of the Financing of Terrorism Adopted by the General Assembly of the United Nations", Resolution 54/109, http://www.un.org/law/cod/finterr.htm, (05.01.2016).

WALCK, C., BILIMORIA, D. (1995), "Editorial: Challenging Globalization Discourses", Journal of Organizational Change Management, 8(4), 3-5.

VUJAKOVIC, P. (2010), "How to Measure Globalisation? A New Globalisation Index (NGI)", FIW Working Paper, 46, https://ideas.repec.org/p/wsr/wpaper /y2010i046.html, (18.12.2015).

WEISS, T. G. (2000), "Governance, Good Governance and Global Governance: Conceptual and Actual Challenges", Third World Quarterly, 21(5), 795-814.

WEISS, T. G., GORDENKER, L. (1996), NGOs, the UN, and Global Governance, Colorado Lynne Rienner Publishers, USA.

WENDT, A. (1992), "Anarchy is What States Make of It: The Social Construction of Power Politics", International Organization, 46(2), 391-425. 
WITTE, J. M., REINICKE, W. H., BENNER, T. (2000), "Beyond Multilateralism: Global Public Policy Networks", International Politics and Society, 2, 176-188.

ZÜRN, M. (1998), "The Rise of International Environmental Politics-A Review of Current Research", World Politics, 50(4), 617-649.

ZÜRN, M. (2013), "Globalization and Global Governance", Handbook of International Relations, (Ed. W.Karsnaes, T.Risse, B.A.Simmons), SAGE Publications, London, 401-425.

http://www.fatf-gafi.org/about/membersandobservers/\#d.en.3147, (10.01.2016).

http://www.fatf-gafi.org/about/, (10.01.2016).

http://www.fatf-gafi.org/countries/, (10.01.2016).

http://www.fatf-gafi.org/publications/?hf $=10 \& b=0 \& s=\operatorname{desc}($ fatf_releasedate), (10.01.2016).

http://breakingenergy.com/2016/03/02/irans-long-road-to-reintegrating-with-theworld-financial-system/, (14.06.2016).

http:/www.idsa.in/idsastrategiccomments/PakistanCastigatedforDeficienciesinCou nterTerroristFinancingRegime_SKSaini_170308, (14.06.2015).

http://www.finmin.nic.in/press_room/2011/Press_Release_FATF_25022011.pdf, (10.06.2016).

http://www.argaam.com/en/article/articledetail/id/380050, (14.06.2016). 